\title{
Prevalence of skin disorders in primary and secondary school age children in Canakkale, Turkey: a community-based survey
}

\author{
Aysegul Uludağ ${ }^{1}$, Sevilay Oguz Kılıc², Selda Isık², Yusuf Haydar Ertekin ${ }^{1}$, Murat Tekin¹, Sibel Cevizci², \\ Zerrin Ogretmen ${ }^{2}$, Naci Topaloglu ${ }^{4}$, Erkan Melih Sahin ${ }^{1}$, Birol Cıbık ${ }^{1}$ \\ ${ }^{1}$ Department of Family Medicine, Faculty of Medicine, Canakkale Onsekiz Mart University, Canakkale, Turkey \\ ${ }^{2}$ Department of Dermatology, Faculty of Medicine, Canakkale Onsekiz Mart University, Canakkale, Turkey \\ ${ }^{3}$ Department of Public Health, Faculty of Medicine, Canakkale Onsekiz Mart University, Canakkale, Turkey \\ ${ }^{4}$ Department of Pediatrics, Faculty of Medicine, Canakkale Onsekiz Mart University, Canakkale, Turkey
}

\begin{abstract}
Introduction: Skin lesions may be of dermatological importance, affect appearance, and cause problems communicating with peers and may be especially more significant in childhood.

Aim: Information on the prevalence of pediatric dermatoses in Western Turkey. This study was aimed to define the existing data.

Material and methods: A cross-sectional study was conducted in Canakkale, Turkey, in September-December 2013. It involved 1,957 students from five randomly selected primary and secondary schools. Each student was interviewed for age, gender, and family history, and a dermatologic examination was performed by a dermatologist. Data were coded and analyzed.

Results: Of the students, $79.9 \%$ revealed at least one dermatosis. The most common disease was benign neoplasms (76\%), followed by pigmentary disorders (26.8\%), and xerosis (5.8\%). In primary schools, the acquired melanocytic nevus, hypopigmented macule, and xerosis; in secondary school the acne was statistically significantly more common. Acne and xerosis was more common in girls, and pityriasis alba was statistically more common in boys. Students who had at least one dermatosis were positively correlated with monthly income.

Conclusions: In Turkish school age children, the prevalence of dermatosis is $79.9 \%$. It may be due to not using preventive means for adequate protection from the sun and other environmental factors. Infectious dermatosis and atopic dermatitis are rare and it may depend on the adequacy of public health work.
\end{abstract}

Key words: dermatosis, pediatrics, prevalence.

\section{Introduction}

Epidemiological studies to detect skin lesions in childhood emphasize the prevalence and importance of the disease in the population and have an effect on directing health policies and actions. These epidemiological studies are difficult, due to both time and costs but have the characteristic of carrying clues about the health of future generations.
The majority of skin lesions in the childhood period are due to acutely developing diseases. Additionally, diseases like psoriasis, atopic dermatitis, and vitiligo affect patients for a lifetime. Skin lesions may be of dermatological importance, affect appearance, and cause problems communicating with peers and may be especially more significant in childhood. 


\section{Aim}

This study is a community-based study to determine skin lesions in the pediatric period in Turkey, and was aimed to determine the prevalence and characteristics of skin lesions in primary and secondary school children in a provincial city, Canakkale, in Western Turkey.

\section{Material and methods}

The study had a cross-sectional design and was completed in September-December 2013 in primary and secondary schools in the city center of the Canakkale province. The study was completed by a team from the Canakkale Onsekiz Mart University, Medical Faculty, Family Practice, Public Health, Pediatrics, Dermatology, Physical Therapy and Rehabilitation, and Ear, Nose and Throat Departments under the name School Health Screening Project. Some of the findings identified during this project were shared in this study.

\section{Population}

The population of the study was 5-14 year-old students enrolled in primary and secondary schools in the city of Canakkale. In the city of Canakkale, there were a total of 7,579 students enrolled in primary and secondary schools for the 2012-2013 education year [1]. As the population is known, the sample size was calculated to be 366 students. However, as no previous health screening has been conducted in the region, no prevalence results were available in this region. Additionally, in the School Health Screening Project, one school was randomly selected from each of the five neighborhoods in the city of Canakkale. The minimum sample size was determined as $366 \times 5=1,830$ and we aimed to reach all students enrolled in these schools. A total of 1,957 students attending the five schools participated in the project at a rate of $66.1 \%$. The total enrollments in the schools and project participation rates are shown in Table 1.

\section{Permission and consent}

This study was planned under the auspices of the School Health Screening Project. Completed by the teaching staff from Canakkale Onsekiz Mart University, Medical Faculty, Family Practice, Public Health, Pediatric Health and Diseases, Dermatology, Physical Therapy and Rehabilitation, and Ear, Nose and Throat Departments, this project received permission from the Canakkale Onsekiz Mart University Ethics Committee dated 27.12.2012 and numbered 050.99-214 and from the Provincial National Education Directorate dated 23.09.2013.

Meetings were held with the administrators of the schools planned to participate in the Health Screening Project and permission was sought. In the schools, they were asked to provide an appropriate location for the team to conduct examinations. The project aims and methods were explained to the parents of students at a meeting and they were requested to provide written and verbal permission by completing a Parental Consent Form.

\section{Participants}

Volunteers who accepted participation were included in the study. Those without parental consent were excluded from the study. Permission was granted to parents who wished to accompany their children to the examination. A total of 1,957 students agreed to participate in the study.

\section{Survey}

The Parental Consent Form given to parents to complete also included questions regarding the sociodemographic characteristics of the child and family and contact information. This form requested the student's prenatal and natal history, history of allergies, chronic diseases, the parents' height and weight, chronic diseases and habits and monthly income levels. The students' identifying information, anthropometric measurements, and examination information were noted on the Examination Form used during the study.

\section{Measurements}

Height measurement: Among anthropometric measurements, height was measured standing with shoes removed using a Standing Height Measure.

Weight measurement: Weight was measured using a calibrated digital scale with $0.01 \mathrm{~kg}$ sensitivity. During measurements the digital scale was placed on the floor, the student removed his or her shoes, and any other heavy objects, and stood with the weight spread evenly between the feet.

Waist and hip circumference measurement: Waist and hip circumference measurements were made with a non-elastic tape measure. Waist circumference measurements were taken midway between the lowest rib on the right and the crest of the iliac bone with the abdomen relaxed. Hip measurements were made with the student standing tall, at the highest point of the hip. Measurements had sensitivity of $0.01 \mathrm{~cm}$. Waist and hip

Table 1. Schools and participation rate of the Project

\begin{tabular}{ccc}
\hline Schools & Total, $\boldsymbol{n}$ & Participation rate of the Project, $\boldsymbol{n}$ (\%) \\
\hline 1 & 430 & $361(84.5)$ \\
\hline 2 & 615 & $438(71.2)$ \\
\hline 3 & 572 & $482(84.3)$ \\
\hline 4 & 688 & $412(59.8)$ \\
\hline 5 & 655 & $264(40.3)$ \\
\hline Total & $\begin{array}{c}2660 \\
(100.0 \%)\end{array}$ & $1957(66.1)$ \\
\end{tabular}


Table 2. Distrubition of students demografic variables

\begin{tabular}{|c|c|c|c|c|}
\hline Demografic variables & $\begin{array}{l}\text { Primary school } \\
\quad(n=1386)\end{array}$ & $\begin{array}{l}\text { Secondary school } \\
(n=571)\end{array}$ & Statistical analysis* & $P$-value \\
\hline \multicolumn{5}{|l|}{ Gender: } \\
\hline Girls & $693(35.4 \%)$ & $257(13.1 \%)$ & $\chi^{2}=4.403$ & 0.045 \\
\hline Boys & $693(35.4 \%)$ & $55(16.0 \%)$ & & \\
\hline Age & $7.31 \pm 1.24$ & $11.63 \pm 1.16$ & $t=-71.432$ & $<0.001$ \\
\hline History of allergy & $204(13.8 \%)$ & $60(4.1 \%)$ & $\chi^{2}=2.245$ & 0.101 \\
\hline Monthly income (TL) & $1893.7 \pm 1226.6$ & $1439.6 \pm 1025.3$ & $t=4.491$ & $<0.001$ \\
\hline \multicolumn{5}{|c|}{ Antropometric measurements: } \\
\hline Height, mean \pm SD $[\mathrm{cm}]$ & $126.8 \pm 8.7$ & $149.4 \pm 10.1$ & $t=-49.461$ & $<0.001$ \\
\hline Weight, mean \pm SD $[\mathrm{cm}]$ & $27.4 \pm 0.2$ & $44.4 \pm 0.5$ & $t=-36.716$ & $<0.001$ \\
\hline $\mathrm{BMI}$, mean $\pm \mathrm{SD}\left[\mathrm{kg} / \mathrm{m}^{2}\right]$ & $16.8 \pm 2.9$ & $19.6 \pm 4.3$ & $t=-16.993$ & $<0.001$ \\
\hline
\end{tabular}

${ }^{*} t$-independent $t$ test, $\chi^{2}$-chi-square test, $p<0.05$ is significant. TL - Turkish lira, BMI-body mass index.

circumference measurements were taken when the students were behind a screen.

\section{Practice}

Students were taken to a previously arranged and organized examination room. The students were divided into groups of five and accompanied by class teachers and parents. The boys and girls were taken inside at separate times. The skin lesion examinations were completed by a member of the Dermatology Department in an environment with sufficient light, in screened units. During the examination, the students could not see or touch each other. The students were examined without clothes and their skin lesions were noted. The whole body was examined, excluding the genital region. The examination findings were recorded on examination forms unique to each student.

\section{Statistical analysis}

Data were evaluated with SPSS version 18.0. Descriptive statistics of variables such as mean, median,

Table 3. The dermatologic conditions

\begin{tabular}{lcc}
\hline $\begin{array}{l}\text { Pediatric } \\
\text { dermatosis }\end{array}$ & $\boldsymbol{N}$ & Percentage \\
\hline 1 & 623 & 31.8 \\
\hline 2 & 559 & 28.6 \\
\hline 3 & 261 & 13.3 \\
\hline 4 & 86 & 4.4 \\
\hline 5 & 26 & 1.3 \\
\hline 6 & 7 & 0.4 \\
\hline 7 & 2 & 0.1 \\
\hline 8 & 1 & 0.1 \\
\hline
\end{tabular}

standard deviation values, and frequency values were calculated. Skin findings were evaluated with the Kolmogorov-Smirnoff test for normal distribution. It was observed that skin variables were in accordance with normal distribution. To evaluate the relationship between variables, the independent $t$-test, $\chi^{2}$ test, and Mann-Whitney $U$-test were applied. Correlations were evaluated with the Kendal tau b test.

\section{Results}

\section{Participants}

The study included 1,957 students in five schools in the city center of Canakkale, in grades $1-8$, with students between the ages of 5 and 14 years. The distribution of students in primary and secondary school according to the Turkish education system are shown in Table 2.

\section{Dermatological findings}

There were 392 (20.1\%) students with no skin findings and $1(0.1 \%)$ student with eight findings. The prevalence of skin lesions among students is given in Table 3.

The distribution of gender and dermatosis of students in primary and secondary school according to the Turkish education system is given in Table 4.

In primary school students, there was greater acquired melanocytic nevus $\left(\chi^{2}=28,696 ; p<0.05\right)$, hyper and hypopigmented macules $\left(\chi^{2}=29.039 ; p<0.05\right)$, and xerosis $\left(\chi^{2}=4.747 ; p<0.05\right)$, while in secondary school students, there was greater acne $\left(\chi^{2}=205.205 ; p<0.05\right)$ in a statistically significant amount.

Primary school students had acquired melanocytic nevus, hypo/hyper pigmentation, and xerosis, while secondary school students had acquired melanocytic nevus, acne, and hypo/hyperpigmentation, in that order. Seventy-six (3.9\%) students were referred to the dermatology 
Table 4. Frequencies and percentages of pediatric dermatosis

\begin{tabular}{|c|c|c|c|}
\hline Variable** & $\begin{array}{c}\text { Primary } \\
\text { school } \\
n(\%)\end{array}$ & $\begin{array}{c}\text { Secondary } \\
\text { school } \\
n(\%)\end{array}$ & $\begin{array}{c}\text { Total* }^{*} \\
(\%)\end{array}$ \\
\hline \multicolumn{4}{|l|}{ Dermatitis: } \\
\hline Atopic dermatitis & $64(4.7)$ & $12(1.8)$ & 3.9 \\
\hline Contact dermatitis & $9(0.7)$ & $6(1.1)$ & 0.7 \\
\hline Seborrhoeic dermatitis & $14(1.0)$ & $10(1.8)$ & 1.2 \\
\hline Nummular dermatitis & $0(0.0)$ & $2(0.4)$ & 0.1 \\
\hline Pityriasis alba & $76(5.5)$ & $25(4.4)$ & 5.2 \\
\hline \multicolumn{4}{|l|}{ Viral infections: } \\
\hline Warts & $40(2.9)$ & $11(1.9)$ & 2.6 \\
\hline Herpes simplex & $16(1.2)$ & $5(0.9)$ & 1.1 \\
\hline \multicolumn{4}{|l|}{ Fungal infections: } \\
\hline Tinea pedis & $12(0.9)$ & $6(1.1)$ & 0.9 \\
\hline Tinea corporis & $6(0.4)$ & $8(1.4)$ & 0.7 \\
\hline Tinea unguium & $7(0.5)$ & $5(0.9)$ & 0.6 \\
\hline \multicolumn{4}{|l|}{ Pigmentation disorders: } \\
\hline Café au lait & $32(2.3)$ & $20(3.5)$ & 2.7 \\
\hline Freckles & $64(4.6)$ & $20(3.5)$ & 4.3 \\
\hline Leukoderma & $10(0.7)$ & $3(0.5)$ & 0.7 \\
\hline Vitiligo & $4(0.3)$ & $2(0.4)$ & 0.4 \\
\hline Albinism & $1(0.1)$ & 0.0 & 0.1 \\
\hline $\begin{array}{l}\text { Post-inflammatory } \\
\text { hypopigmentation }\end{array}$ & $214(15.4)$ & $37(6.5)$ & 12.8 \\
\hline $\begin{array}{l}\text { Post-inflammatory } \\
\text { hyperpigmentation }\end{array}$ & $90(6.5)$ & $24(4.2)$ & 5.8 \\
\hline \multicolumn{4}{|l|}{ Hair disorders: } \\
\hline Alopecia areata & $3(0.2)$ & 0.0 & 0.2 \\
\hline Hypertrichosis & $4(0.3)$ & $3(0.5)$ & 0.4 \\
\hline \multicolumn{4}{|l|}{ Sebaceous gland disorders: } \\
\hline Acne & $15(1.1)$ & $103(5.3)$ & 6.0 \\
\hline \multicolumn{4}{|l|}{ Papulosquamous diseases: } \\
\hline Psoriasis & $3(0.2)$ & $3(0.5)$ & 0.3 \\
\hline Lichen nitidus & $32(2.3)$ & $5(0.9)$ & 1.9 \\
\hline
\end{tabular}

\begin{tabular}{|c|c|c|c|}
\hline Variable $^{\star *}$ & $\begin{array}{c}\text { Primary } \\
\text { school } \\
n(\%)\end{array}$ & $\begin{array}{c}\text { Secondary } \\
\text { school } \\
n(\%)\end{array}$ & $\begin{array}{c}\text { Total* } \\
(\%)\end{array}$ \\
\hline \multicolumn{4}{|l|}{ Sweat gland disorders: } \\
\hline Miliaria & $1(0.1)$ & $5(0.9)$ & 0.3 \\
\hline \multicolumn{4}{|c|}{ Benign neoplasms and hyperplasia: } \\
\hline Milia & $22(1.6)$ & $7(1.2)$ & 1.5 \\
\hline $\begin{array}{l}\text { Congenital melanocytic } \\
\text { nevus }\end{array}$ & $39(2.8)$ & $41(7.2)$ & 4.1 \\
\hline Hemangioma & $18(2.0)$ & $2(0.4)$ & 1.0 \\
\hline $\begin{array}{l}\text { Acquired melanocytic } \\
\text { nevus }\end{array}$ & $973(70.2)$ & $297(52.0)$ & 64.9 \\
\hline Spitz nevus & $1(0.1)$ & 0.0 & 0.1 \\
\hline Nevus flammeus & $2(0.1)$ & 0.0 & 0.1 \\
\hline Becker nevus & $2(0.1)$ & $1(0.2)$ & 0.2 \\
\hline Mongolian spot & $2(0.1)$ & 0.0 & 0.1 \\
\hline Scar & $41(3.0)$ & $29(5.1)$ & 3.6 \\
\hline Keloid & $6(0.4)$ & 0.0 & 0.3 \\
\hline Other & 0 & $2(0.4)$ & 0.1 \\
\hline Nail dystrophy & $20(1.4)$ & $3(0.5)$ & 1.2 \\
\hline \multicolumn{4}{|c|}{ Unclassified other group diseases: } \\
\hline Keratosis pilaris & $66(4.8)$ & $22(3.9)$ & 4.5 \\
\hline Xerosis & $91(6.6)$ & $23(4.0)$ & 5.8 \\
\hline Xeroderma & $2(0.1)$ & $1(0.2)$ & 0.2 \\
\hline Pityriasis capitis simplex & $2(0.1)$ & $6(1.1)$ & 0.4 \\
\hline Striae distensae & $1(0.1)$ & $5(0.9)$ & 0.3 \\
\hline Ecchymosis & $24(1.7)$ & $1(0.2)$ & 1.3 \\
\hline Insect bite & $21(1.5)$ & 0.0 & 1.1 \\
\hline Telangiectasia & $30(2.2)$ & $12(2.1)$ & 2.1 \\
\hline Livedo reticularis & $69(5.0)$ & $18(3.2)$ & 4.4 \\
\hline At least one skin finding & $1142(82.4)$ & $423(74.1)$ & 79.90 \\
\hline $\begin{array}{l}\text { Non-cutaneous } \\
\text { manifestations }\end{array}$ & 244 (17.6) & $148(25.9)$ & 20.10 \\
\hline Total & 1386 (100) & $571(100)$ & 100.00 \\
\hline
\end{tabular}

${ }^{\star}$ Column percentage is taken, ${ }^{* *}$ more than one diagnoses is defined.

clinic after the skin examination. $2.4 \%$ of students were referred to the clinic because of the acquired melanocytic nevus evaluation. The most common dermatoses are given Table 5.

\section{Factors related to dermatological findings}

There was a weak positive correlation between students with at least one dermatosis and monthly income levels (Kendal $\tau$ b $r=0.102 ; p<0.05$ ), but no correlation with age (Kendal $\tau b r=0.15 ; p>0.05$ ). There was a weak positive correlation between the presence of acne and age (Kendal $\tau \mathrm{br}=0.267 ; p<0.05$ ) and BMI (Kendal $\tau \mathrm{b} r=0.182 ; p<0.05)$.

\section{Discussion}

In the current study, conducted on school-age children, at least one skin finding was found in $79.9 \%$ of students aged $5-14$ years. The most frequent skin findings in primary school children were acquired melanocytic nevus, post-inflammatory hypopigmentation, and 
Table 5. The most common dermatoses among children by gender

\begin{tabular}{lcccc}
\hline Dermatosis & $\begin{array}{c}\text { Girls } \\
n(\%)\end{array}$ & $\begin{array}{c}\text { Boys } \\
n(\%)\end{array}$ & $\chi^{2}$ & $P_{\text {-value* }}$ \\
\hline Acquired melanocytic nevus & $659(69.3)$ & $611(60.7)$ & 16.237 & $<0.001$ \\
\hline Post-inflammatory hypopigmentation & $112(11.8)$ & $139(13.8)$ & 16.732 & 0.183 \\
\hline Acne & $78(8.2)$ & $40(4.0)$ & 15.498 & $<0.001$ \\
\hline Xerosis & $64(6.7)$ & $50(5.0)$ & 2.797 & 0.094 \\
\hline Pityriasis alba & $34(3.6)$ & $67(6.7)$ & 9.440 & 0.002 \\
\hline${ }^{*}<0.05$ is & & & &
\end{tabular}

${ }^{*} P<0.05$ is significant.

xerosis, while in secondary school children, the most frequent findings were acquired melanocytic nevus, acne, and post-inflammatory hypopigmentation. When comparisons were made based on gender, girls had acquired melanocytic nevus and acne, while male students had acquired melanocytic nevus, post-inflammatory hypopigmentation, and pityriasis alba. Acne frequency increased with age. Monthly income levels increased with at least one dermatosis, and body mass index (BMI) increased the presence of acne. The prevalence of infectious dermatosis was low.

\section{Prevalence of dermatologic findings}

Population-based studies show differences in the prevalence of skin lesions depending on the region. Total prevalence was $86.9 \%$ in a population-based study in Egypt in all age groups, while prevalence was $35.0 \%$ in primary school children in Nigeria, $31.3 \%$ of $6-21$-yearolds in Hong Kong and $45.3 \%$ of the population above 5 years in India had at least one skin finding [2-5]. In Turkey, the prevalence of at least one dermatosis in the preschool age group was found to be $30.3 \%$ in a communitybased study [6]. In the current study, the prevalence of at least one skin lesion was $79.9 \%$. This rate is very high, though the prevalence of benign lesions was greater.

Of those reporting to dermatology clinics in Japan, in the $6-10$ age group, the most frequent complaints were atopic dermatitis, warts, and dermatitis, while in the 1115 age group, acne was most frequent [7]. In Switzerland and China, the most frequent complaints of 6-10 yearold children were atopic dermatitis, acquired melanocytic nevus, and warts [8, 9]. In a study of school-age children in Egypt, the most frequent skin lesion was benign neoplasm known as melanocytic nevus, milia, and hypertrophic scars with a prevalence of 87.0\% [10]. Davis et al. [11] scanned American data and determined that the most frequent skin findings according to race and roots were acne and eczema. Henderson et al. [12] retrospectively evaluated visits to a dermatology clinic in the 10-11-year old age group in the United States, and determined acne, dermatitis, and nevus were most frequent.

In a study in Turkey by Tamer et al. [13], the researchers found that the most frequent complaints were contact dermatitis, warts, and atopic dermatitis for children aged 6-10 years, while acne, contact dermatitis, and warts were the most frequent among children aged 11-15 years that reported to the clinics. In the current study, the most frequent skin findings in primary school children were acquired melanocytic nevus, post-inflammatory hypopigmented macules, and xerosis, while in secondary school children, the most frequent findings were acquired melanocytic nevus, acne, and post-inflammatory hypopigmented macules.

Psoriasis and vitiligo are chronic skin diseases that may affect social life in the early stages of life. The prevalence of psoriasis in Germany is $0.1-0.8 \%$ in children aged 1-18 years [14]. In China, the life-long prevalence of vitiligo is $0.56 \%$ [15]. In the current study, the prevalence of vitiligo is $0.1 \%$ and of psoriasis is $0.4 \%$, with similar rates in other countries.

The most important factors affecting the prevalence of skin lesions are weather and environmental conditions. In regions with poor sanitation and humid climates, infectious skin lesions are more frequently encountered. Epidemiological studies have shown that the season of the study may affect results. The current study was completed in the fall, when schools were newlyopened, according to the Turkish National Education System, in a town with moderate climatic conditions. As a result, the distribution of skin lesions in children was dominated by hypo-/hyper-pigmented macular lesions and freckles, linked to sun exposure with no protection. The population of the main city in the province, on the coast of the Aegean Sea and located on the Canakkale straits is 120,000. Due to appropriate environmental and social conditions, children play outside. As other studies in different regions of Turkey have not been populationbased ones, but were completed in dermatology clinics, they do not fully reflect the dermatological findings in the population. In the current study, the frequency of atopic dermatitis was $5.1 \%$. Atopic dermatitis had the highest incidence in Switzerland and India, with the second highest incidence in Japan, while in Nigeria, yearly incidence more than doubled, and in Denmark, the life-long prevalence was determined as $21.3 \%$ [5, 8, 16, 17]. We believe the lower incidence of atopic dermatitis compared to other skin findings is due to the community-based na- 
ture of the study and may be linked to the climatic and natural conditions in the province of the study.

Frequently, in school-age children, the etiology of infectious skin diseases includes bacterial, parasitic, viral, and fungal causes. Nigeria has most fungal infections with $36.1 \%$, with a rate of $31.2 \%$ of pediculosis capitis in primary school children. In Egypt, infectious diseases, mostly pediculosis capitis, had a rate of $50.2 \%$ in school children $[10,18]$. Epidemiological studies in Europe have found the prevalence of infectious diseases to be very low with pediculosis capitis having the highest prevalence [8]. In the current study, the most frequent infectious skin diseases were warts and herpes simplex infections. Pediculosis capitis infection in public areas such as schools may affect the entire population. This infection may not have been found due to the seasonal characteristics of the study. Environmental health precautions may have been appropriately applied to prevent the formation and spread of the infection.

\section{Conclusions}

Though in Turkish school-age children the prevalence of at least one skin lesion was $79.9 \%$, mostly these were benign findings due to environmental conditions. The high prevalence of skin lesions due to exposure to the sun may be related to not using protective factors. The infectious skin findings were very low, and formed no risk to public health. The prevalence of atopic dermatitis was lower than in other races in this population-based study.

\section{Conflict of interest}

Authors declare no conflict of interest.

\section{References}

1. National Education Statistics Formal Education, Training indicators, p: 30. www.sgb.meb.gov.tr. Accessed on August 10, 2013.

2. Abdel-Hafez K, Abdel-Aty MA, Hofny ER. Prevalence of skin diseases in rural areas of Assiut Governorate, Upper Egypt. Int J Dermatol 2003; 42: 887-92.

3. Ogunbiyi AO, Owoaje EME, Ndahi A. Prevalence of skin disorders in school children in Ibadan, Nigeria. Pediatr Dermatol 2005; 22: 6-10.

4. Fung WK, Lo KK. Prevalence of skin disease among school children and adolescents in a Student Health Service Center in Hong Kong. Int I Dermatol Pediatr Dermatol 2000; 17: 440-6.

5. Grills N, Grills C, Spelman T, et al. Prevalence survey of dermatological conditions in mountainous north India. Int J Dermatol 2012; 51: 579-87.

6. Karaca S, Kulaç M, Demirel R, et al. The prevalence of skin conditions in preschool education centers in Afyonkarahisar. Turkiye Klinikleri J Dermatol 2007; 17: 4-8.

7. Furue M, Yamazaki S, Jimbow K, et al. Prevalence of dermatological disorders in Japan: a nationwide, cross-sectional, seasonal, multicenter, hospital-based study. J Dermatol 2011; 38: 310-20.

8. Wenk C, Itin PH. Epidemiology of pediatric dermatology and allergology in the region of Aargau, Switzerland. Pediatr Dermatol 2003; 20: 482-7.

9. Hon KL, Leung TF, Wong Y, et al. Skin diseases in Chinese children at a pediatric dermatology center. Pediatr Dermatol 2004; 21: 109-12.

10. El-Khateeb EA, Lotfi RA, Abd Elaziz KM, El-Shiekh SE. Prevalences of skin diseases among primary schoolchildren in Damietta, Egypt. Int J Dermatol 2014; 53: 609-16.

11. Davis SA, Narahari S, Feldman SR, et al. Top dermatologic conditions in patients of color: an analysis of nationally representative data. J Drugs Dermatol 2012; 11: 466-73.

12. Henderson MD, Abboud J, Cogan CM, et al. Skin-of-color epidemiology: a report of the most common skin conditions by race. Pediatr Dermatol 2012; 29: 584-9.

13. Tamer E, Ilhan MN, Polat M, et al. Prevalence of skin diseases among pediatric patients in Turkey. J Dermatol 2008; 35: 413-8.

14. Matusiewicz D, Koerber A, Schadendorf D, et al. Childhood psoriasis: an analysis of German health insurance data. Pediatr Dermatol 2014; 31: 8-13.

15. Wang X, Du J, Wang T, et al. Prevalence and clinical profile of vitiligo in China: a community-based study in six cities. Acta Derm Venereol 2013; 93: 62-5.

16. Yahya $\mathrm{H}$. Change in pattern of skin disease in Kaduna, northcentral Nigeria. Int J Dermatol 2007; 46: 936-43.

17. Mortz CG, Lauritsen JM, Bindslev-Jensen C, Andersen KE. Prevalence of atopic dermatitis, asthma, allergic rhinitis, and hand and contact dermatitis in adolescents. The Odense Adolescence Cohort Study on Atopic Diseases and Dermatitis. Br J Dermatol 2001; 144: 523-32.

18. Murgia V, Bilcha KD, Shibeshi D. Community dermatology in Debre Markos: an attempt to define children's dermatological needs in a rural area of Ethiopia. Int I Dermatol 2010; 49: 666-71. 